\title{
Ptgs2 activation by endotoxin mediates the decrease in Igf1, but not in Igfbp3, gene expression in the liver
}

\author{
A I Martín, M López-Menduiña, E Castillero, M Granado, M A Villanúa and A López-Calderón \\ Department of Physiology, Faculty of Medicine, University Complutense of Madrid, 28040 Madrid, Spain \\ (Correspondence should be addressed to A López-Calderón; Email: alc@med.ucm.es)
}

\begin{abstract}
The aim of this work was to analyse the role of cyclooxygenase-2 $(P \operatorname{tgs} 2)$ in endotoxin-induced decrease in Igf1 and Igf binding protein-3 (Igfbp3). For this purpose, male Wistar rats were injected with lipolysaccharide (LPS) and/or the Ptgs2 inhibitor meloxicam. LPS induced a significant decrease $(P<0 \cdot 01)$ in serum concentrations of Igf1 and Igfbp3 and their mRNAs in the liver. Meloxicam administration prevented the inhibitory effect of LPS injection on serum Igf1 and its liver mRNA. By contrast, meloxicam administration was unable to modify the inhibitory effect of LPS on Igfbp 3. LPS injection also induced a decrease in GH receptor (Ghr) mRNA in the liver, and meloxicam attenuated this effect. In order to elucidate a direct action of the Ptgs2 inhibitor on the liver cells, the effect of LPS
\end{abstract}

and/or meloxicam was studied in primary cultures of hepatocytes with non-parenchymal cells. LPS decreased Igf1 and Ghr but not Igfbp 3 gene expression in liver cells in culture. Meloxicam administration attenuated the inhibitory effect of LPS on Igf1 mRNA, whereas it did not modify the decrease in Ghr mRNA after LPS. The effect of meloxicam on the LPS response does not seem to be mediated by changes in nitric oxide or tumour necrosis factor (Tnf) production, since meloxicam did not modify the stimulatory effect of LPS on nitric oxide or Tnf $\alpha$ gene expression both in vivo and in vitro. All these data suggest that LPS-induced Ptgs 2 activation decreases Igf1 gene expression in liver cells.

Journal of Endocrinology (2008) 198, 385-394

\section{Introduction}

One of the endocrine alterations induced by sepsis and inflammation is the inhibition of growth hormone (GH)insulin-like growth factor I (Igf1) system. The decrease in these anabolic hormones contributes to the negative nitrogen balance, growth inhibition and cachexia observed in chronic inflammation (Delano \& Moldawer 2006, Thissen 2007). All these alterations lead to a slower recovery from the illness, and increased mortality.

Sepsis can be experimentally induced in rats by endotoxin (lipolysaccharide, LPS) administration, since it reproduces most of the physiological responses triggered by sepsis. One of the mechanisms by which endotoxin inhibits serum concentrations of Igf1 is by inducing GH resistance and decreasing its gene expression in the liver (Defalque et al. 1999, Priego et al. 2003a). The inhibitory effect of LPS can be exerted directly on the hepatocyte, since LPS is able to decrease Igf1 gene expression in hepatocyte cultures (Priego et al. 2006).

We have previously reported that LPS-induced decrease in serum and liver Igf1 seems to be due to inducible nitric oxide synthase (Nos2) activation, since Nos2 inhibitors are able to prevent the inhibitory effect of LPS on liver Igf1 gene expression both in vivo and in vitro (Priego et al. 2004, 2006). However, the Nos 2 inhibition was not able to prevent the LPS-induced decrease in Igf1 mRNA when the hepatocytes were cultured with Kupffer cells (Priego et al. 2006). These data indicate that nitric oxide release is not the only factor responsible for the inhibition of Igf1 gene expression after endotoxin exposure.

The role of Kupffer cells on LPS-induced Igf1 inhibition was also evidenced by the fact that Kupffer cell depletion by gadolinium administration prevents the inhibitory effect of LPS on GH receptor $(G h r)$, Igf1 and Igf binding protein-3 (Igfbp3) gene expression (Granado et al. 2006). Kupffer cells (resident liver macrophages) have a pivotal role in liver inflammatory response; they release cytokines and prostanoids after LPS exposure, which might decrease Igf1 gene expression. Tumour necrosis factor- $\alpha(\operatorname{Tn} f \alpha)$ has been reported to inhibit Igf1 mRNA induction after GH stimulation both in vivo (Yumet et al. 2002) and in vitro (Ahmed et al. 2006). However, it has been demonstrated that suppression of Tnf $\alpha$ by pentoxiphylline fails to restore both circulating Igf1 levels and GH sensitivity in rats injected with LPS (Colson et al. 2003).

When activated by LPS, Kupffer cells release the cyclooxygenase-2 (Ptgs2) products, prostaglandin $\mathrm{E}_{2}$ (Ptges2) and thromboxane $\mathrm{A}_{2}$ (Tbxa2r) (Keller et al. 2005, Bezugla et al. 2006). We have shown that Ptgs 2 inhibition is able to prevent chronic arthritis-induced decrease in serum concentration of Igf1 and its gene expression in the liver (Granado et al. 2007). Taking into account that Ptgs 2 is 
expressed in Kupffer cells, and not in hepatocytes, incubated with LPS (Martín-Sanz et al. 1998), it is possible that Ptgs2 activation can contribute to the LPS-induced decrease in Igf1 gene expression in the liver.

The present study was designed in order to elucidate the possible inhibitory effect of Ptgs 2 activation on LPS-induced inhibition of $I g f 1$ and $I g f b p 3$ gene expression in the liver. For this purpose, the effect of meloxicam on the LPS-induced decrease in Ghr, Igf1 and Igfbp3 has been studied. In addition, studies have been performed using primary cultures of hepatocytes with non-parenchymal cells in order to analyse the possible interaction between Nos 2 and Ptgs 2 induction by LPS stimulation.

\section{Materials and Methods}

Male Wistar rats weighing 200-225 g were used in all experiments; they were obtained from Harlan (Barcelona, Spain). Rats were housed 3-4 per cage, under controlled conditions of temperature $\left(22^{\circ} \mathrm{C}\right)$ and light (lights on from 0730 to $1930 \mathrm{~h}$ ). Food and water were made available ad libitum. Rats were quarantined for 1 week before any experimental use. All procedures on animals were carried out according to the guidelines recommended by the EU for the care and use of laboratory animals, and were approved by the Complutense University Animal Care Committee.

\section{In vivo experiment}

Rats were randomly assigned to the treatment groups. Twenty rats were i.p. injected with $250 \mu \mathrm{g} / \mathrm{kg}$ LPS (serotype 055:B5, Sigma Chemical Co.) in $250 \mu \mathrm{l}$ sterile saline. Another 20 rats were injected with saline. Half of the rats in each group were simultaneously i.p. injected with the selective Ptgs 2 inhibitor, meloxicam (1 mg/kg, Sigma), while the other half were injected with $250 \mu \mathrm{l}$ sterile saline. Meloxicam at this dosage decreased serum concentrations of Ptges 2 and prevented arthritis-induced decrease in liver Igf1 gene expression (Granado et al. 2007).

Rats received the treatments at $1700 \mathrm{~h}$ and at $0800 \mathrm{~h}$ the following day. This LPS administration protocol was shown to decrease levels of serum Igf1 and its mRNA in the liver (Priego et al. 2003a). Meloxicam administration was not able to modify the LPS-induced decrease in food and water intake. All animals were killed by decapitation at $1200 \mathrm{~h}, 19 \mathrm{~h}$ after the first, and $4 \mathrm{~h}$ after the second LPS and/or meloxicam injection. Liver was removed, frozen immediately in liquid nitrogen, and stored at $-80^{\circ} \mathrm{C}$ for isolation of liver RNA. Blood was allowed to clot, and the serum was stored at $-20{ }^{\circ} \mathrm{C}$ for Igf1, Igfbp3 and nitrite/nitrate assays.

\section{In vitro experiments}

The role of Ptgs 2 and Nos 2 induction on the inhibitory effect of LPS on Ghr and Igf1 gene expression was studied in hepatocytes and non-parenchymal cell cultures, as previously reported (Granado et al. 2008). Both hepatocytes and non-parenchymal cells from one culture were isolated from the same rat liver. Rats were anaesthetized with pentobarbital (Sigma, Chemical Co). The liver was perfused in situ through the portal vein at a flow rate of $40 \mathrm{ml} / \mathrm{min}$ with calcium-free buffer at $37^{\circ} \mathrm{C}$ for $15 \mathrm{~min}$, and then the liver was digested with a $0 \cdot 04 \%$ collagenase (Roche) for another $5-10 \mathrm{~min}$ at $37^{\circ} \mathrm{C}$. The liver was transferred to a Petri dish and the cells were obtained by gentle raking with a comb and filtered through a $100 \mu \mathrm{m}$ mesh to remove cell aggregates and tissue debris. Hepatocytes were separated from nonparenchymal cells by differential centrifugation at $25 \mathrm{~g}$ (three times, $5 \mathrm{~min}$ each). Hepatocyte purity was assessed by microscopy and was $>90 \%$; viability was measured by trypan blue exclusion and was $>80 \%$. Hepatocytes were kept on ice while the non-parenchymal cells were isolated.

Non-parenchymal cells were isolated from supernatant of the differential centrifugations and were then centrifuged at $650 \mathrm{~g}$ for $6 \mathrm{~min}$ at $4{ }^{\circ} \mathrm{C}$. The pellet was suspended in a $50 \mathrm{ml}$ culture medium and centrifuged at $650 \mathrm{~g}$ for $7 \mathrm{~min}$. Medium consisted of Williams' medium E (Gibco) with L-glutamine $(2 \mathrm{mM})$, insulin $(1 \mu \mathrm{M})$, HEPES $(15 \mathrm{mM})$, penicillin + streptomycin $(100$ units $/ \mathrm{ml}+100 \mu \mathrm{g} / \mathrm{ml})$ and $10 \%$ low-endotoxin calf serum. Non-parenchymal cells were finally suspended and plated with hepatocytes in a proportion of $3: 2\left(3 \cdot 10^{6}\right.$ hepatocytes $/ 2 \cdot 10^{6}$ non-parenchymal cells in $5 \mathrm{ml}$ medium).

The culture medium was replaced with fresh medium $24 \mathrm{~h}$ before starting all experiments. A concentration of $100 \mathrm{ng} / \mathrm{ml}$ LPS was used; in earlier experiments we used a higher dose to stimulate hepatocytes, but when hepatocytes were cultured with non-parenchymal cells the effect of LPS on Igf1 can be observed at a lower LPS dose (Priego et al. 2006), since the effect of LPS was enhanced.

\section{Real-time PCR}

RNA was extracted by the guanidine thiocyanate method using a commercial kit (Ultraspec RNA, Biotecx Laboratories Inc., Houston, TX, USA). The integrity and the concentration of the RNA were confirmed using agarose gel electrophoresis. For RT-PCR analysis, $1 \mu \mathrm{g}$ liver or cocultures cell total RNA was reverse-transcribed with Quantiscript Reverse Transcription kit (Qiagen Combh Hilden). Primers for PCR (Table 1) were obtained from Roche by using the Exiqon Universal Probe Library (Igfbp3 and Ghr) or from previously published sequences of Igf1, Tnfo (Dehoux et al. 2004), Ptgs2 (Bianchi et al. 2005) and hypoxanthine-guanine phosphorybosyl transferase (Hprt1) (Peinnequin et al. 2004).

Each real-time PCR consisted of $10 \mathrm{ng}$ total RNA equivalents, $1 \times$ Takara SYBR Green Premix Ex Taq (Takara BIO INC, Otsu, Shiga, Japan) and $300 \mathrm{nM}$ forward and reverse primers in a reaction volume of $25 \cdot 5 \mu \mathrm{l}$. Reactions were carried out on a SmartCycler (Cepheid, Sunnyvale, CA, USA). Parameters included an initial activation of hotStarTaq DNA polymerase at $95^{\circ} \mathrm{C}$ for $15 \mathrm{~s}$, followed by 40 cycles of denaturation at $94^{\circ} \mathrm{C}$ for $15 \mathrm{~s}$, annealing at $60^{\circ} \mathrm{C}$ and extension 
Table 1 Primers for real-time PCR

Forward primer $\left(5^{\prime}-3^{\prime}\right)$

Gene

Igf1

Ghr

Igfbp3

Ptgs2

Tnfo

Hprt1
GCTATGGCTCCAGCATTCG TCCCGGGATCTATTCAGCTA GGAAAGACGACGTGCATTG TACAAGCAGTGGCAAAGGCC GCCACCAGCTCTTCTGTCT CTCATGGACTGATTATGGACAGGAC
Reverse primer $\left(5^{\prime}-3^{\prime}\right)$

Product (bp)

TCCGGAAGCAACACTCATCC

TGTTTGCTCCAGCAGAGACAT

GCGTATTTGAGCTCCACGTT

CAGTATTGAGGAGAACAGATGGG

GTCTGGGCCATGGAACTGAT

GCAGGTCAGCAAAGAACTTATAGCC

\section{Product (bp}

62

99

78

303

100

122 at $72{ }^{\circ} \mathrm{C}$ for $30 \mathrm{~s}$. Specific amplification was confirmed by the presence of one single peak in the melting curve plots. In addition, the PCR products were analysed by agarose gel electrophoresis. Results were calculated as the percentage of control rats, using the cycle threshold $2\left(C_{t}\right)$ methods (Livak \& Schmittgen 2001) with the Hprt1 as the reference gene.

\section{IGF1, PTGES2 and nitrite+ nitrate determinations}

Serum IGF1 concentrations were measured by a doubleantibody RIA. The IGF1 antiserum (UB2-495) was a gift from Dr Underwood and Dr Van Wik, and it is distributed by the Hormone Distribution Program of NIDDK through the National Hormone and Pituitary Program. Levels of Igf1 were expressed in terms of IGF1 from Gropep Ltd (Adelaide, Australia). The intra-assay coefficient of variation was $8 \%$. All samples were run in the same assay.

Serum concentrations of PTGES2 were measured by an enzymeimmunoassay system using a commercial kit (Amersham Biosciences) following the manufacturer's instructions.

Nitrite + nitrate concentration in the serum and culture medium was measured by a modified method of Griess assay, described by Miranda et al. (2001). Serum was deproteinized to reduce turbidity by centrifugation through a $30 \mathrm{kDa}$ molecular mass filter using a Centrifree micropartition device with a YM30 ultrafiltration membrane (Amicon Division, Millipore Corporation, Bedford, TX, USA) at $300 \mathrm{~g}$ for $1 \mathrm{~h}$ at $37^{\circ} \mathrm{C}$ for $300 \mu \mathrm{l}$ samples. To $100 \mu \mathrm{l}$ vanadium chloride, $25 \mu \mathrm{l}$ serum or $100 \mu \mathrm{l}$ medium were mixed; the Griess reagents were added very soon after. The determination was performed at $37^{\circ} \mathrm{C}$ for $30 \mathrm{~min}$. The absorbance was measured at $540 \mathrm{~nm}$. Nitrite + nitrate concentration was calculated using a $\mathrm{NaNO}_{2}$ standard curve and expressed as $\mu \mathrm{M}$.

\section{Western ligand blot}

Serum concentrations of IGFBP3 were measured by western blot. Two microliters of serum were diluted in sample buffer and boiled for $2 \mathrm{~min}$ at $90{ }^{\circ} \mathrm{C}$, loaded onto $1 \%$ SDS- $12 \cdot 5 \%$ polyacrylamide gels, and electrophoressed under non-reducing conditions. Proteins were transferred onto nitrocellulose sheets (Hybond-C extra, Amersham). The membranes were dried and blocked for $1 \mathrm{~h}$ with 5\% non-fat dry milk, 0.1\% Tween (Sigma), in Tris-buffered saline. Membranes were probed overnight at $4{ }^{\circ} \mathrm{C}$ with ${ }^{125}$ I-labelled Igf1 $\left(1.5 \times 10^{6}\right.$ c.p.m. $\left./ \mathrm{ml}\right)$. The nitrocellulose sheets were then washed, dried and exposed at $-80^{\circ} \mathrm{C}$ to X-ray film (Kodak X-Omat AR, Eastman Kodak) and to two intensifying screens for 1-4 days according to the signal obtained. The signals of the film were quantified by densitometry using a PC-Image VGA24 program for Windows. The density of the IGFBP3 band in each lane was expressed as the percentage of the mean density of sera from control rats injected with saline.

\section{Statistical analysis}

Statistics were computed using the statistics program STATGRAPHICS plus for Windows (Statpoint Inc., Madrid, Spain). Data are presented as means \pm s.E.M. and differences among experimental groups were analysed by two-way ANOVA. Post hoc comparisons were made by using a subsequent LSD multiple range test. Serum concentrations of nitrites + nitrates and liver Tnf $\alpha$ mRNA data in the in vivo experiment were subjected to $\log$ transformation, since variances showed a log-normal distribution. Statistical significance was set at $P<0 \cdot 05$.

\section{Results}

\section{In vivo experiment}

The serum concentrations of IGF1 and its gene expression in the liver, in rats injected with saline, LPS, meloxicam or LPS and meloxicam are shown in Fig. 1. LPS injection induced a significant $(P<0 \cdot 01)$ decrease in serum concentrations of IGF1 and mRNA in the liver $(P<0 \cdot 01)$. The Ptgs 2 inhibitor meloxicam prevented the inhibitory effect of LPS on IGF1, since the rats injected with LPS and meloxicam had higher serum IGF1 $(P<0 \cdot 01)$ and Igf1 mRNA in the liver $(P<0 \cdot 05)$ than the control rats injected with LPS. In the control rats, meloxicam decreased serum concentrations of Igf1 $(P<0 \cdot 01)$, whereas the Igf1 mRNA in the liver was similar in the rats injected with saline and those injected with meloxicam. In the control rats, LPS injection decreased Ghr mRNA in the liver $(P<0 \cdot 01$, Fig. 1C). LPS also decreased Ghr mRNA in the rats injected with meloxicam $(P<0 \cdot 01)$. However, this decrease was lower in the rats injected with meloxicam than in the control rats $(36 \cdot 6 \pm 7 \%$ of the control rats injected with 
meloxicam versus $58 \pm 3 \cdot 4 \%$ of the control rats injected with saline, $P<0 \cdot 05)$.

In the rats injected with LPS there was a significant decrease in the serum concentrations of Igfbp3 and gene expression in the liver $(P<0 \cdot 01$, Fig. 2$)$. In contrast to the Igf1 data, meloxicam administration was not able to modify
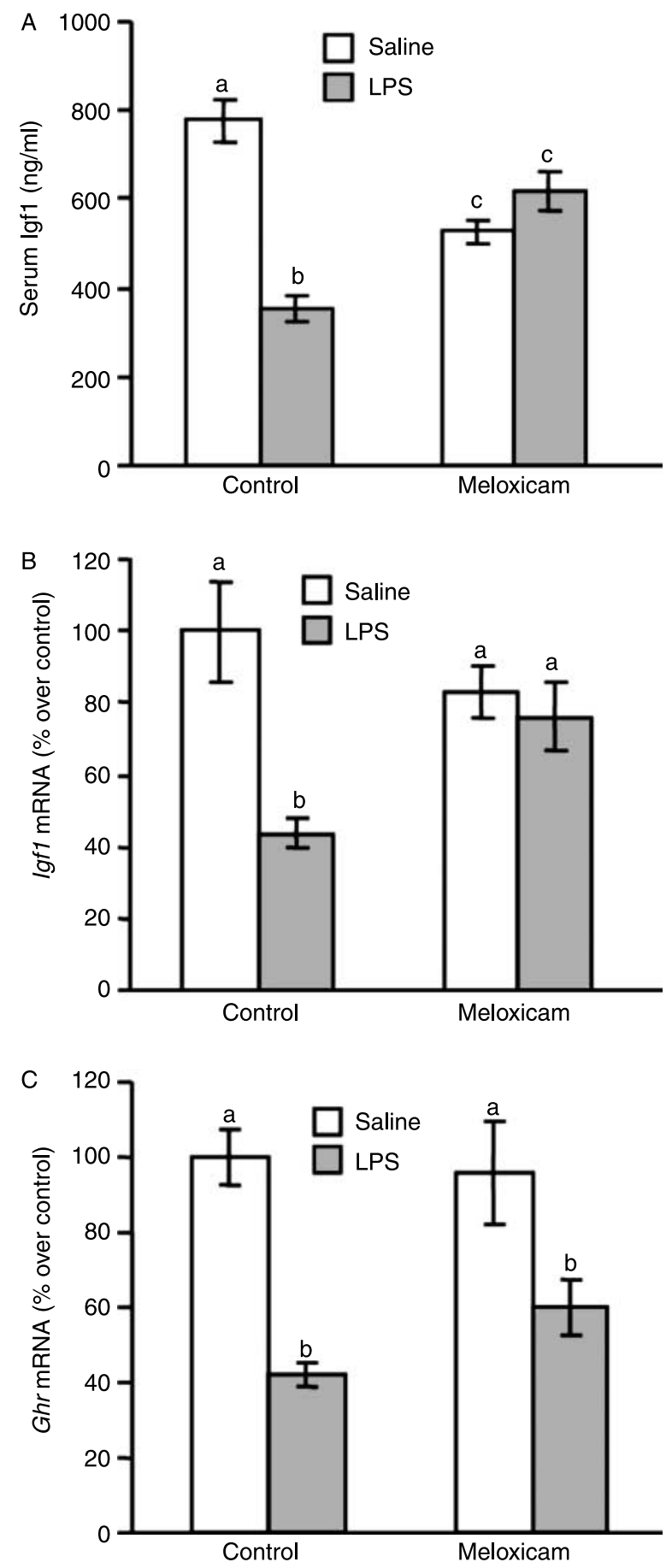

the inhibitory effect of LPS on IGFBP3, since the rats injected with LPS and meloxicam had similar serum IGFBP3 and liver Igfbp 3 mRNA to the levels in rats injected with LPS alone (Fig. 2). Meloxicam administration did not modify the serum concentrations of IGFBP3 or the liver Igfbp 3 mRNA in control rats.

In control rats, LPS increased Ptgs 2 mRNA in the liver $(193 \pm 33 \%$ vs $100 \pm 16 \%$ in control rats injected with saline, $P<0 \cdot 05)$. The effect of LPS and meloxicam administration on serum concentrations of nitrites + nitrates is shown in Fig. 3A. As expected, LPS injection increased the serum nitrite + nitrate levels $(P<0 \cdot 01)$. Meloxicam increased the serum concentration of nitrites + nitrates in control rats $(P<0 \cdot 05)$, but not in the rats injected with LPS. The effect of LPS and meloxicam administration on liver Tnf $\alpha$ mRNA was similar to the effect on serum nitrites + nitrates (Fig. 3B). Both LPS and meloxicam increased the Tnf $\alpha$ mRNA in the liver, but the increase was only significant in the control rats injected with LPS $(P<0 \cdot 05)$. In the rats injected with meloxicam, LPS administration did not modify Tnf $\alpha$ mRNA.

\section{In vitro experiment: liver cell cultures}

LPS at the concentration of $100 \mathrm{ng} / \mathrm{ml}$ induced a significant increase in Ptgs $2 \mathrm{mRNA}$ in liver cells $(463 \pm 57$ vs $100 \pm 10$ in the cells incubated with medium alone, $P<0 \cdot 01)$ and in the PTGES2 in the culture medium $(P<0 \cdot 01$, Fig. 4$)$. The Ptgs 2 inhibitor, meloxicam, prevented the stimulatory effect of LPS on Ptges2 release (Fig. 4).

As in the in vivo experiment, $100 \mathrm{ng} / \mathrm{ml}$ of LPS decreased Igf1 and Ghr gene expression in liver cell cultures $(P<0 \cdot 01$, Fig. 5). Meloxicam attenuated the inhibitory effect of LPS on Igf 1 gene expression, since the Igf $1 \mathrm{mRNA}$ in the cells incubated with LPS and meloxicam was higher $(P<0 \cdot 05)$ than in the cells incubated with LPS alone (Fig. 5A). By contrast, meloxicam was not able to modify the LPS-induced decrease in Ghr mRNA (Fig. 5B). Meloxicam alone did not modify Igf1 or Ghr mRNA in the cultured cells.

Unsuspectedly, the addition of LPS to the culture medium did not significantly decrease Igfbp 3 gene expression

Figure 1 Serum concentrations of (A) Igf1, (B) Igf1 mRNA in the liver and (C) Ghr mRNA in the liver in male rats i.p. injected with saline, meloxicam (1 mg/kg), LPS $(0.25 \mathrm{mg} / \mathrm{kg})$ or with meloxicam and LPS. Igf1 mRNA was measured by real-time PCR as described in the material and methods, and is presented as percentage of the mean value in control rats treated with saline by analysing the CT numbers corrected by CT readings of corresponding internal Hprt1 mRNA controls. There was an interaction between the effect of meloxicam and LPS on serum concentration of Igf $1\left(F_{1,37}=39, P<0 \cdot 01\right)$ and on liver Igf1 mRNA $\left(F_{1,38}=6, P<0 \cdot 05\right)$, since LPS decreased the serum concentrations of Igf1 and the Igf1 mRNA in the liver in the rats injected with saline, but not in those that were injected with meloxicam. LPS decreased Ghr mRNA $\left(F_{1,37}=27, P<0 \cdot 01\right)$ in the liver. Results are expressed as mean \pm s.E.M. $(n=9-11$ rats). Values without the same letter are significantly different, $P<0 \cdot 05$. 

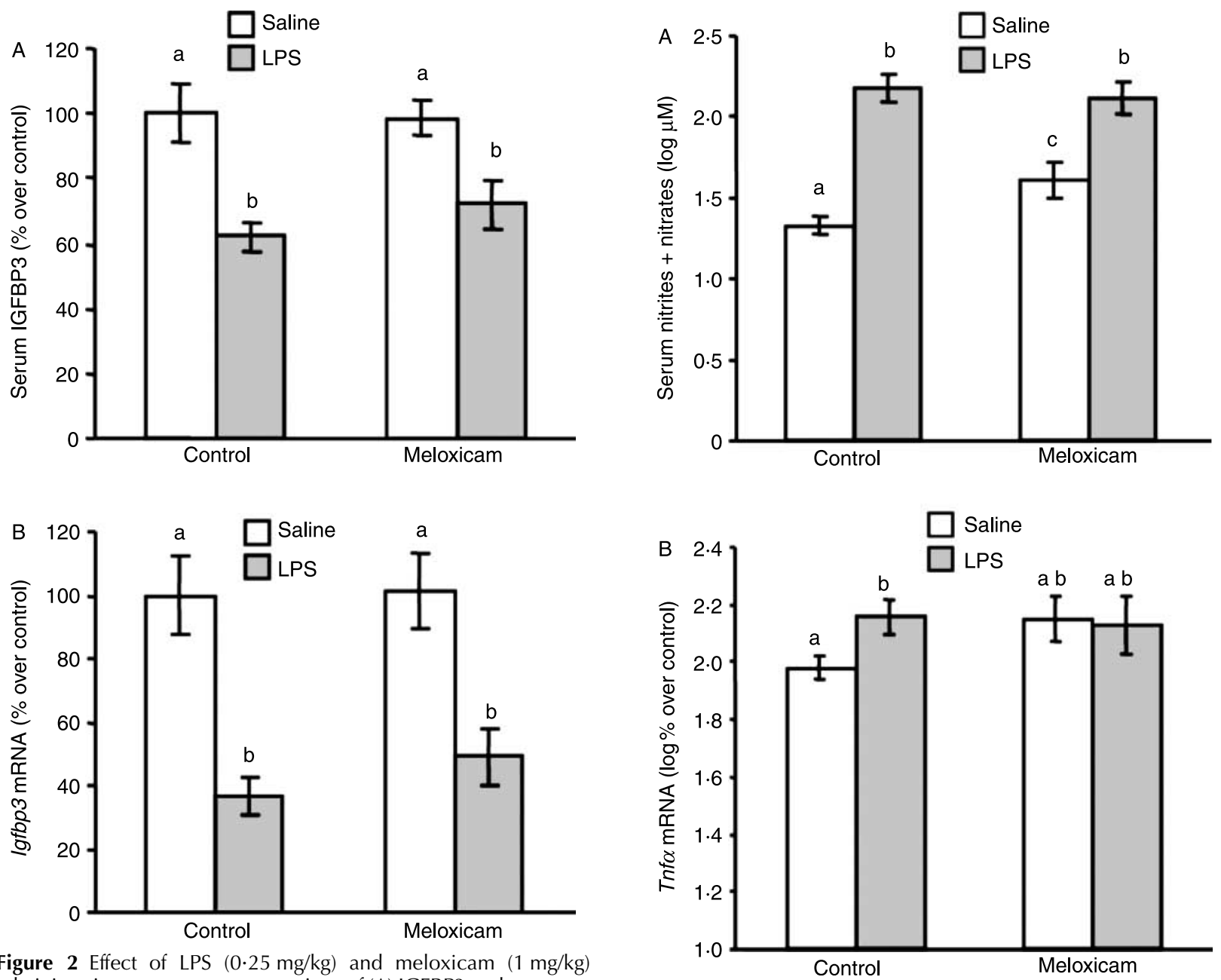

Figure 2 Effect of LPS $(0.25 \mathrm{mg} / \mathrm{kg})$ and meloxicam $(1 \mathrm{mg} / \mathrm{kg})$
administration on serum concentrations of (A) IGFBP3 and (B) Igfbp3 mRNA in the liver. Serum concentrations of IGFBP3 were determined by ligand blot using ${ }^{125}$ I-Igf1. Igfbp 3 mRNA was measured by real-time PCR by analysing the CT numbers corrected by CT readings of corresponding internal Hprt1 mRNA controls. Results are expressed as percentage of the control rats injected with saline, for at least eight rats per group. LPS injection decreased serum concentration of IGFBP3 $\left(F_{1,37}=33, P<0 \cdot 01\right)$ and liver lgfbp3 mRNA $\left(F_{1,39}=31, P<0 \cdot 01\right)$. Data are the mean \pm s.E.M. Values without the same letter are significantly different, $P<0 \cdot 05$.

in the cells, although LPS tended to decrease it (Fig. 5C). Meloxicam did not modify I $g f b p 3$ mRNA.

The nitrite + nitrate concentration in the culture medium was higher in the cells cultured with meloxicam than in the cells cultured with medium alone $(P<0 \cdot 01$, Fig. 6). LPS induced a similar increase in the concentrations of nitrite + nitrate in control cells and in the cells incubated with meloxicam (Fig. 6A). Tnf $\alpha$ mRNA in the liver cells was also increased by LPS $(P<0 \cdot 01)$. Meloxicam addition to the culture medium increased Tnfo gene expression $(P<0 \cdot 05)$, and LPS was not able to further increase Tnf $\alpha$ mRNA in the liver cells cultured with meloxicam (Fig. 6B).

Figure 3 Effect of meloxicam administration (1 mg/kg) on (A) the serum concentrations of nitrites + nitrates and (B) Tnf $\alpha$ mRNA in the liver in rats injected with LPS or saline. Tnf $\alpha$ mRNA was determined by real-time PCR, and is presented as percentage of the mean value in control rats treated with saline by analysing the $\mathrm{CT}$ numbers corrected by CT readings of corresponding internal Hprt1 mRNA controls. There was an interaction between the effect of meloxicam and LPS

$\left(F_{1,39}=3 \cdot 8, P<0 \cdot 05\right)$, since meloxicam increased serum nitrites + nitrates in the rats injected with saline, but not in those that received LPS. Data are the mean \pm S.E.M. for $8-10$ rats per group. Values without the same letter are significantly different $P<0 \cdot 05$.

\section{Discussion}

Our data show that the inhibitory effect of LPS on IGF1 is prevented by administration of the Ptgs 2 inhibitor meloxicam. By contrast, the LPS-induced decrease in IGFBP3 in vivo does not seem to be significantly affected by meloxicam. LPS does not decrease Igfbp 3 gene expression in the liver cells in culture, whereas it exerts a potent inhibitory effect on Igf1 and Ghr gene expression. These data suggest that Igf 1 and Igfbp 3 are regulated by different mechanisms during the inflammatory response induced by endotoxin. We have 


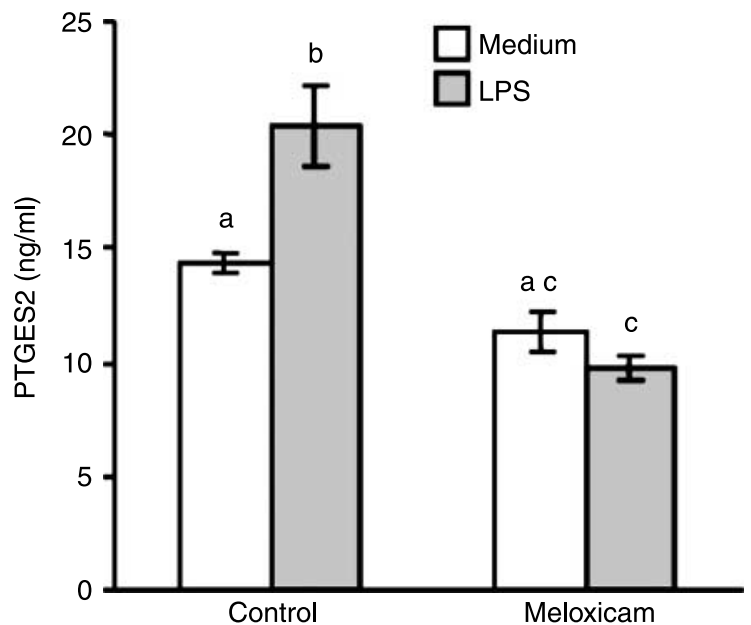

Figure 4 Effect of incubation with meloxicam $\left(10^{-5} \mathrm{M}\right)$ on the LPS $(100 \mathrm{ng} / \mathrm{ml})$-induced Ptges2 release in liver cell cultures. There was an interaction between the effect of meloxicam and LPS $\left(F_{1,30}=10\right.$, $P<0 \cdot 01$ ), since LPS increased PTGES2 concentration in the culture medium in control cells but not in those incubated with meloxicam. Results are expressed as mean \pm S.E.M. ( $n=7-9$ wells). Values without the same letter are significantly different, $P<0 \cdot 05$.

previously suggested this hypothesis (Priego et al. 2003b) since, in Lewis rats, LPS decreased Igfbp3 (Priego et al. 2003b), whereas both Igf1 and Ghr were not modified by endotoxin (Priego et al. 2002). Although Igf1 and Igfbp 3 genes in the liver are positively regulated by $\mathrm{GH}$, other stimuli differentially affect them. For example, in cocultures of rat hepatocytes and Kupffer cells cAMP decreases Igfbp3, whereas it increases Igf1 biosynthesis (Scharf et al. 2001). Furthermore, glucocorticoids inhibit Igf1, whereas they increase Igfbp 3 mRNA in the liver (Luo \& Murphy 1990, Koedam et al. 2000, Priego et al. $2005 b$ ). It has been reported that diabetes-induced decrease in Igf1 can be secondary to the increased release of glucocorticoids and the decrease in Igfbp 3 due to other factors (Unterman et al. 1993). Taking into account that insulin increases Igfbp 3 gene transcription (Villafuerte et al. 1997), the lack of insulin can be the cause of the decrease in Igfbp 3 gene expression in the liver. In diabetic rats, corticosterone at a high dose decreases IGF1, whereas at a lower dose increases IGFBP3 (Rodgers et al. 1995). All these data indicate that IGF1 and IGFBP3 are not always modified in a parallel fashion. Furthermore, in a model of chronic inflammation, such as adjuvant-induced arthritis, serum concentrations of IGF1 are decreased, whereas those of IGFBP3 are increased (Ibáñez de Cáceres et al. 1990).

The lack of a significant effect of LPS on Igfbp 3 gene expression in the cultured liver cells suggests that the inhibitory effect of LPS on Igfbp 3 in vivo seems to be mediated by a non-hepatic factor. The data indicate that LPS or cytokines do not directly inhibit Igfbp 3 gene expression. It has been reported that IL6, IL1b and TNF increase the biosynthesis of IGFBP3 in primary cocultures of hepatocytes and Kupffer cells, whereas the biosynthesis of IGF1 is
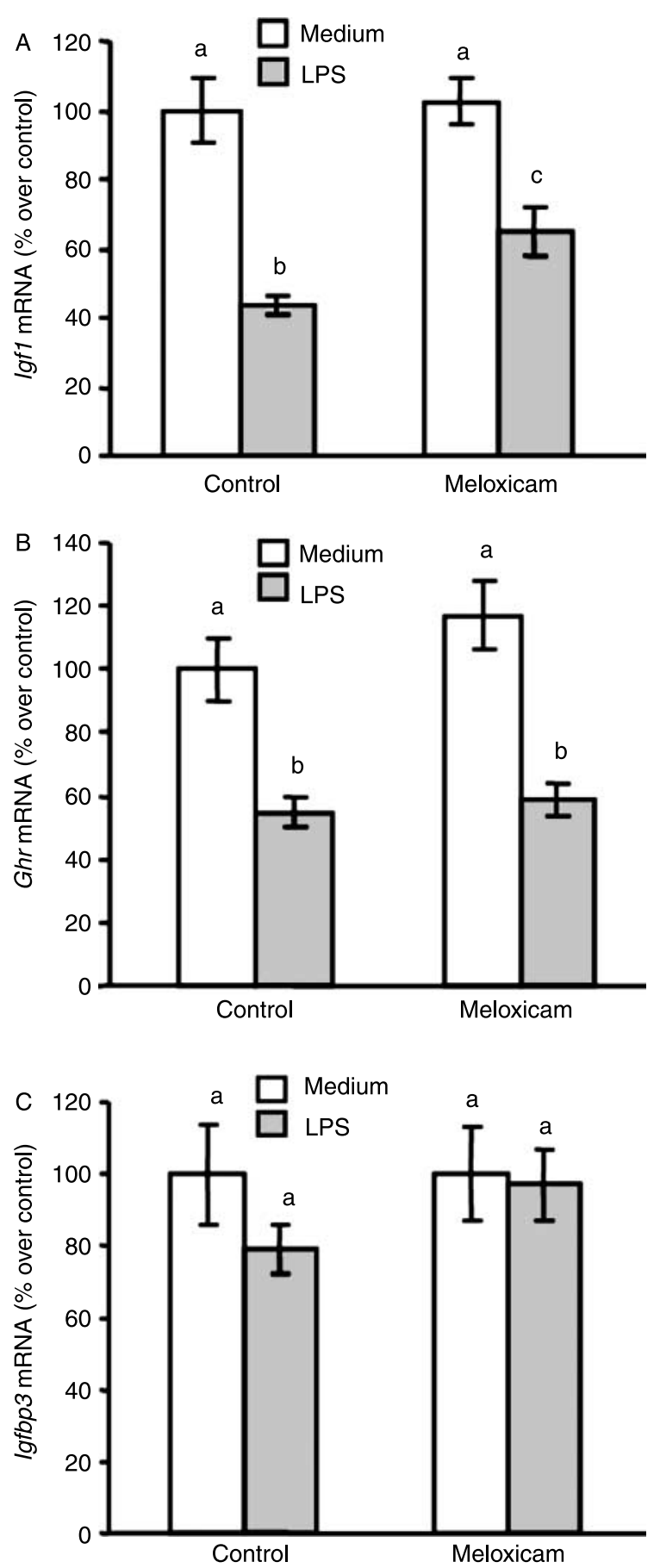

Figure 5 Effect of meloxicam $\left(10^{-5} \mathrm{M}\right)$ and LPS $(100 \mathrm{ng} / \mathrm{ml})$ on (A) Igf1, (B) Ghr and (C) Igfbp3 mRNA in liver cell cultures. Igf1, Ghr and Igfbp3 mRNA were measured by real-time PCR, and results are expressed as percentage of the control cells incubated with medium alone by analysing the CT numbers corrected by CT readings of corresponding internal Hprt1 mRNA controls. LPS decreased Igf1 $\left(F_{1,55}=40, P<0 \cdot 01\right)$ and $\operatorname{Ghr}\left(F_{1,57}=35, P<0 \cdot 01\right)$ mRNA. Data are expressed as mean \pm S.E.M. ( $n=13-15$ wells). Values without the same letter are significantly different, $P<0 \cdot 05$. 

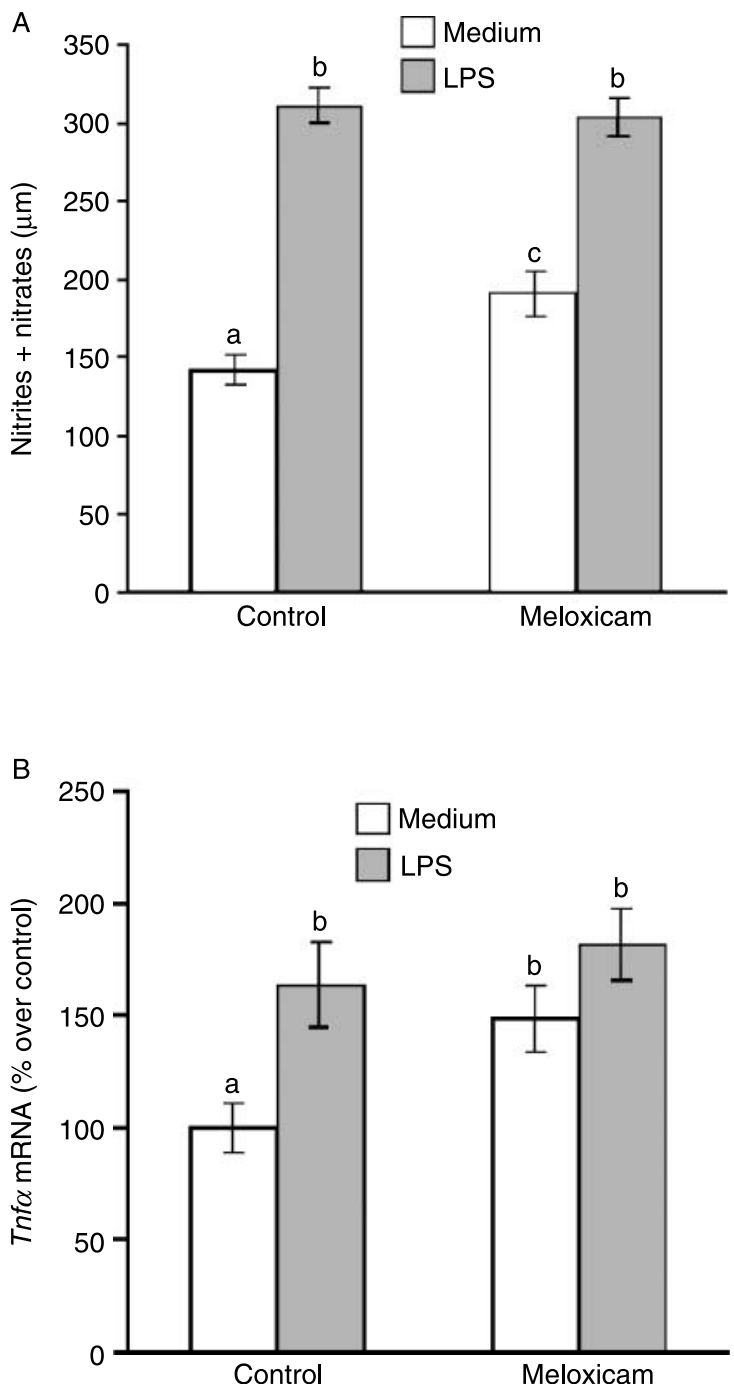

Figure 6 (A) Nitrites + nitrates in the culture medium and (B) Tnfo mRNA in liver cells cultured with meloxicam $\left(10^{-5} \mathrm{M}\right)$ and LPS (100 ng/ml). Tnfo mRNA was measured by real-time PCR, and results are expressed as percentage of the control cells incubated with medium alone by analysing the CT numbers corrected by CT readings of corresponding internal Hprt1 mRNA controls. There was an interaction between the effect of meloxicam and LPS on the concentration of nitrites + nitrates in the culture medium

$\left(F_{1,59}=5 \cdot 6, P<0 \cdot 05\right)$, since meloxicam increased nitrites + nitrates in the cells incubated with medium alone, but not in the cells incubated with LPS. Both meloxicam $\left(F_{1,57}=4 \cdot 2, P<0 \cdot 05\right)$ and LPS $\left(F_{1,57}=8 \cdot 6, P<0 \cdot 01\right)$ increased Tnf $\alpha$ mRNA. Data are expressed as mean \pm S.E.M. $(n=14-15$ wells). Values without the same letter are significantly different, $P<0 \cdot 05$.

inhibited (Lelbach et al. 2001). The stimulatory in vitro effect of cytokines on Igfbp3 has been described in other cell types such as salivary gland tumour (Katz et al. 1999) and human monocytic cell line GLI1 (Agnese et al. 2002). Similar to our data, no effect of LPS on Igfbp 3 has been observed in primary rata microglia cultures, whereas LPS decreased Igfbp 5 and -6
(Chesik et al. 2004). All these data indicate that the inhibitory effect in vivo of LPS on Igfbp3 is not exerted directly by endotoxin or cytokines on a hepatic level.

The fact that LPS decreased Igf1 gene expression directly in the liver cell cultures indicates that LPS has an inhibitory effect on Igf1 gene expression per se. However, we cannot exclude that part of the inhibitory effect of LPS administration in vivo can be secondary to a decrease in food intake. Nevertheless, we have previously reported that LPS administration is able to decrease both serum IGF1 and Igf1 mRNA in fasted rats (Granado et al. 2008).

The Ptgs 2 activation seems to directly suppress liver Igf1 gene expression, since meloxicam attenuated the inhibitory effect of LPS on liver cells in culture. However, meloxicam in vivo prevented the inhibitory effect of LPS on Igf1 gene expression in the liver, whereas in vitro it only attenuated the LPS-induced decrease in Igf1 mRNA. This difference cannot be explained by the fact that meloxicam was not able to block Ptgs 2 activity, since LPS-induced increase in Ptges 2 release to the culture medium was prevented by meloxicam. One possible explanation could be that part of the in vivo meloxicam effect is an indirect effect, exerted outside the liver. In this sense, we have reported that meloxicam prevents the inhibitory effect of chronic arthritis on both pituitary GH and liver Igf1 gene expression (Granado et al. 2007). In the present data we did not evaluate pituitary GH, since LPS at the dose of $0.25 \mathrm{mg}$ does not significantly decrease $G H$ mRNA (Priego et al. 2003a).

In contrast to the Igf1 response, meloxicam did not modify the LPS-induced decrease in Ghr mRNA in the liver cells in vitro, although the decrease was attenuated in vivo. Taking into account that one of the factors that controls Ghr gene expression is GH (Flores-Morales et al. 2006), and that LPS is able to inhibit pituitary GH secretion (Kasting \& Martin 1982), by increasing hypothalamic somatostatin (Spangelo et al. 1990, Priego et al. 2005a), it is logical to think that pituitary GH can mediate the LPS-induced decrease in Ghr mRNA. In fact, LPS at a low dose $(10 \mu \mathrm{g} / \mathrm{kg})$ increases pituitary GH release, does not modify liver Ghr mRNA and decreases Igf1 mRNA (Priego et al. 2003a). However, at higher doses, LPS decreases pituitary GH, liver Ghr and Igf1 (Priego et al. 2003a). These data support the hypothesis that some of the changes in liver Ghr and Igf1 genes during endotoxin administration are secondary to modifications in pituitary $\mathrm{GH}$, whereas others are exerted directly on liver cells. In the liver LPS very rapidly induces a GH resistance state, since $4 \mathrm{~h}$ after LPS injection there is a decrease in GH post-receptor signalling (Jak2-Stat5a phosphorylation), in spite of the fact that the GHR protein levels are still unchanged (Chen et al. 2007). It has been recently reported that LPS can also directly suppress Ghr expression in vitro by inhibiting Ghr promoter activity (Dejkhamron et al. 2007). However, these authors find that LPS in vivo inhibits Ghr gene expression by a cytokine-dependent mechanism (Denson et al. 2001). It is also possible that the effect of meloxicam in 
the LPS-induced decrease in Ghr and Igf1 in vivo are partly mediated by changes at the pituitary GH.

TNF and nitric oxide were measured as possible mediators of the meloxicam effect, since they inhibit Igf1 gene expression in hepatocytes (Thissen \& Verniers 1997, Ahmed et al. 2006, Priego et al. 2006). Although meloxicam prevented the inhibitory effect of LPS on Igf1 gene expression in the liver, it was not able to prevent the stimulatory effect of LPS on the release of nitrites + nitrates in vivo and in vitro. On the contrary, meloxicam increased nitrites + nitrates in basal conditions both in vivo and in vitro. These paradoxical results are in accordance with those recently reported (Razzak et al. 2008), in which Ptgs 2 inhibition increases NO production in macrophages. Ptgs 2 inhibitors have also been reported to increase nitric oxide production in oestrogenized rat uterus (Cella et al. 2006). These data suggest that PTGS2 products decrease nitric oxide synthesis.

Prostaglandins also have an inhibitory effect on Tnf $\alpha$ gene expression and secretion in macrophages (Kunkel et al. 1988, Treffkorn et al. 2004) and Kupffer cells (Karck et al. 1988), whereas prostaglandin inhibition by indomethacin increases the Tnf $\alpha$ response to LPS stimulation in the rat glial cells (Shemi et al. 2001).

The fact that meloxicam did not prevent Tnfo and nitric oxide response to LPS suggests a direct effect of Ptgs 2 products on Igf1 gene expression, rather than being mediated by nitric oxide or Tnf $\alpha$. In hepatocyte cultures it has been reported that Tnf $\alpha$ was not able to alter basal Igf1 mRNA, but TNF- $\alpha$ inhibits the induction of Igf1 mRNA by GH (Ahmed et al. 2006). Inhibition of $\operatorname{Tnf} \alpha$ release by pentoxifylline administration prevents LPS-induced IL-1, whereas it is not able to prevent the increased release of PTGES2 (Shemi et al. 2001), or the decrease in serum IGF1 and liver Igf1 mRNA (Colson et al. 2003). These data support the hypothesis that Tnfa does not seem to be implicated in the LPS-induced decrease in basal Igf1 gene expression in the liver.

We have previously reported that Nos 2 activation plays an important role in LPS-induced inhibition of GH-Igf1. Aminoguanidine, an Nos2 inhibitor, prevents the LPSinduced activation of hypothalamic somatostatin (Priego et al. 2005a), and the decrease in Igf1 in the liver (Priego et al. 2004). It has been reported that nitric oxide or iNOS activation positively regulates Ptgs 2 gene expression (Salvemini et al. 1993, Yang et al. 2006). In addition, the Nos2 inhibitor aminoguanidine decreases LPS-induced Ptgs2 activation in Kupffer cells (Ahmad et al. 2002), and suppresses prostaglandin production in the LPS-treated animals (Salvemini et al. 1995). Accordingly, it is possible that part of the inhibitory effect of nitric oxide on the GH-Igf1 system can be due to the activation of Ptgs 2 gene expression.

In summary, our data suggest that Ptgs 2 activation plays an important role in the inhibitory effect of LPS on the Igf1 system by directly decreasing Igf1 gene expression in liver cells. On the contrary, Ptgs 2 activation does not seem to be involved in the LPS-induced decrease in $\operatorname{Igfbp} 3$ gene expression in the liver.

\section{Declaration of Interest}

The authors declare that there is no conflict of interest that would prejudice the impartiality of this scientific work.

\section{Funding}

This work was supported by Programa Nacional de Promoción General del Conocimiento, Plan Nacional de Investigación Científica, from Ministerio de Educación Ciencia (BFI-2003-02149), by a fellowship from Gobierno Vasco to E C (BFI06.31), and from Ministerio de Educación y Ciencia to M L-M (BES-2007-16001).

\section{Acknowledgements}

The authors are indebted to Antonio Carmona for technical assistance and to Christina Bickart for the English correction of the manuscript.

\section{References}

Agnese DM, Calvano JE, Hahm SJ, Calvano SE \& Lowry SF 2002 Insulin-like growth factor binding protein-3 is upregulated in LPS-treated THP-1 cells. Surgical Infections 3 119-125.

Ahmad N, Chen LC, Gordon MA, Laskin JD \& Laskin DL 2002 Regulation of cyclooxygenase- 2 by nitric oxide in activated hepatic macrophages during acute endotoxemia. Journal of Leukocyte Biology 71 1005-1011.

Ahmed T, Yumet G, Shumate M, Lang CH, Rotwein P \& Cooney RN 2006 Tumor necrosis factor inhibits growth hormone-mediated gene expression in hepatocytes. American Journal of Physiology-Gastrointestinal and Liver Physiology 291 G35-G44.

Bezugla Y, Kolada A, Kamionka S, Bernard B, Scheibe R \& Dieter P 2006 COX1 and COX-2 contribute differentially to the LPS-induced release of PGE 2 and TxA2 in liver macrophages. Prostaglandins and other Lipid Mediators 79 93-100.

Bianchi A, Moulin D, Sebillaud S, Koufany M, Galteau MM, Netter P, Terlain B \& Jouzeau JY 2005 Contrasting effects of peroxisome-proliferatoractivated receptor (PPAR)gamma agonists on membrane-associated prostaglandin E2 synthase-1 in IL-1beta-stimulated rat chondrocytes: evidence for PPARgamma-independent inhibition by 15-deoxy-Delta12,14prostaglandin J2. Arthritis Research and Therapy 7 R1325-R1337.

Cella M, Aisemberg J, Sordelli MS, Billi S, Farina M, Franchi AM \& Ribeiro ML 2006 Prostaglandins modulate nitric oxide synthase activity early in time in the uterus of estrogenized rat challenged with lipopolysaccharide. European Journal of Pharmacology 534 218-226.

Chen Y, Sun D, Krishnamurthy VM \& Rabkin R 2007 Endotoxin attenuates growth hormone-induced hepatic insulin-like growth factor I expression by inhibiting JAK2/STAT5 signal transduction and STAT5b DNA binding. American Journal of Physiology-Endocrinology and Metabolism 292 E1856-E1862.

Chesik D, Glazenburg K, Wilczak N, Geeraedts F \& De Keyser J 2004 Insulinlike growth factor binding protein-1-6 expression in activated microglia. Neuroreport 15 1033-1037.

Colson A, Willems B \& Thissen JP 2003 Inhibition of TNF-alpha production by pentoxifylline does not prevent endotoxin-induced decrease in serum Igf1. Journal of Endocrinology 178 101-109.

Defalque D, Brandt N, Ketelslegers J-M \& Thissen J-P 1999 GH insensitivity induced by endotoxin injection is associated with decreased liver receptors. American Journal of Physiology 276 E565-E572.

Dehoux M, Van Beneden R, Pasko N, Lause P, Verniers J, Underwood L, Ketelslegers JM \& Thissen JP 2004 Role of the insulin-like growth factor I decline in the induction of atrogin-1/MAFbx during fasting and diabetes. Endocrinology 145 4806-4812.

Dejkhamron P, Thimmarayappa J, Kotlyarevska K, Sun J, Lu C, Bonkowski EL, Denson LA \& Menon RK 2007 Lipopolysaccharide (LPS) directly 
suppresses growth hormone receptor (Ghr) expression through MyD88dependent and-independent Toll-like receptor-4/MD2 complex signaling pathways. Molecular and Cellular Endocrinology 274 35-42.

Delano MJ \& Moldawer LL 2006 The origins of cachexia in acute and chronic inflammatory diseases. Nutrition in Clinical Practice 21 68-81.

Denson LA, Menon RK, Shaufl A, Bajwa HS, Williams CR \& Karpen SJ 2001 TNF-alpha downregulates murine hepatic growth hormone receptor expression by inhibiting Sp1 and Sp3 binding. Journal of Clinical Investigation 107 1451-1458.

Flores-Morales A, Greenhalgh CJ, Norstedt G \& Rico-Bautista E 2006 Negative regulation of growth hormone receptor signaling. Molecular Endocrinolgy 20 241-253.

Granado M, Martín AI, Priego T, Villanúa MA \& López-Calderón A 2006 Inactivation of Kupffer cells by gadolinium administration prevents lipopolysaccharide-induced decrease in liver insulin-like growth factor-I and IGF-binding protein-3 gene expression. Journal of Endocrinology 188 503-511.

Granado M, Martín AI, Villana MA \& López-Calderón A 2007 Experimental arthritis inhibits the insulin-like growth factor-I axis and induces muscle wasting through cyclooxygenase-2 activation. American Journal of PhysiologyEndocrinology and Metabolism 292 E1656-E1665.

Granado M, Martín AI, López-Menduiña M, López-Calderón A \& Villanúa MA 2008 GH-releasing peptide-2 administration prevents liver inflammatory response in endotoxemia. American Journal of Physiology-Endocrinology and Metabolism 294 E131-E141.

Ibáñez de Cáceres I, Villanúa MA, Soto L, Martín I \& López-Calderón A 2000 Igf1 and Igf1-binding proteins in rats with adjuvant-induced arthritis given recombinant human growth hormone. Journal of Endocrinology 165 $537-544$

Karck U, Peters T \& Decker K 1988 The release of tumor necrosis factor from endotoxin-stimulated rat Kupffer cells is regulated by prostaglandin E2 and dexamethasone. Journal of Hepatology 7 352-361.

Kasting NW \& Martin JB 1982 Altered release of growth hormone and thyrotropin induced by endotoxin in the rat. American Journal of Physiology 43 E332-E337.

Katz J, Nasatzky E, Werner H, Le Roith D \& Shemer J 1999 Tumor necrosis factor alpha and interferon gamma-induced cell growth arrest is mediated via insulin-like growth factor binding protein-3. Growth Hormone and IGF Research 9 174-178.

Keller SA, Paxian M, Lee SM, Clemens MG \& Huynh T 2005 Kupffer cell ablation attenuates cyclooxygenase-2 expression after trauma and sepsis. Journal of Surgical Research 124 126-133.

Koedam JA, Hoogerbrugge CM \& Van Buul-Offers SC 2000 Differential regulation of IGF-binding proteins in rabbit costal chondrocytes by Igf1 and dexamethasone. Journal of Endocrinology 165 557-567.

Kunkel SL, Spengler M, May MA, Spengler R, Larrick J \& Remick D 1988 Prostaglandin E2 regulates macrophage-derived tumor necrosis factor gene expression. Journal of Biological Chemistry 263 5380-5384.

Lelbach A, Scharf JG \& Ramadori G 2001 Regulation of insulin-like growth factor-I and of insulin-like growth factor binding protein-1, -3 and -4 in cocultures of rat hepatocytes and Kupffer cells by interleukin-6. Journal of Hepatology 35 558-567.

Livak KJ \& Schmittgen TD 2001 Analysis of relative gene expression data using real-time quantitative PCR and the $2(-$ Delta Delta $\mathrm{C}(\mathrm{T}))$ Method. Methods 25 402-408.

Luo JM \& Murphy LJ 1990 Regulation of insulin-like growth factor binding protein-3 expression by dexamethasone. Molecular and Cellular Endocrinology 74 213-219.

Martín-Sanz P, Callejas NA, Casado M, Díaz-Guerra MJ \& Boscá L 1998 Expression of cyclooxygenase-2 in foetal rat hepatocytes stimulated with lipopolysaccharide and pro-inflammatory cytokines. British Journal of Pharmacology 125 1313-1319.

Miranda KM, Espey MG \& Wink DA 2001 A rapid, simple spectrophotometric method for simultaneous detection of nitrate and nitrite? Nitric Oxide 5 62-71.

Peinnequin A, Mouret C, Birot O, Alonso A, Mathieu J, Clarencon D, Agay D, Chancerelle Y \& Multon E 2004 Rat pro-inflammatory cytokine and cytokine related mRNA quantification by real-time polymerase chain reaction using SYBR green. BMC Immunology $\mathbf{5}$ 3-10.

Priego T, Ibáñez de Cáceres I, Martín AI, Villanúa MA \& López-Calderón A 2002 Glucocorticoids are not necessary for the inhibitory effect of endotoxic shock on serum Igf1 and hepatic Igf1 mRNA. Journal of Endocrinology 172 449-456.

Priego T, Granado M, Ibáñez de Cáceres I, Martín AI, Villanúa MA \& LópezCalderón A 2003a Endotoxin at low doses stimulates pituitary GH whereas it decreases Igf1 and IGF-binding protein-3 in rats. Journal of Endocrinology 179 107-117.

Priego T, Ibáñez de Cáceres I, Martín AI, Villanúa MA \& López-Calderón A $2003 b$ Endotoxin decreases serum IGFBP-3 and liver IGFBP-3 mRNA: comparison between Lewis and Wistar rats. Molecular and Cellular Endocrinology 199 23-28.

Priego T, Ibáñez de Cáceres I, Martín AI, Villanúa MA \& López-Calderón A 2004 NO plays a role in LPS-induced decreases in circulating Igf1 and IGFBP-3 and their gene expression in the liver. American Journal of Physiology-Endocrinology and Metabolism 286 E41-E49.

Priego T, Ibáñez de Cáceres I, Martín AI, Villanúa MA \& LópezCalderón A 2005a Endotoxin administration increases hypothalamic somatostatin mRNA through nitric oxide release. Regulatory Peptides $124113-118$.

Priego T, Granado M, Martín AI, López-Calderón A \& Villanúa MA 2005b Dexamethasone administration attenuates the inhibitory effect of lipopolysaccharide on Igf1 and IGF-binding protein-3 in adult rats. Journal of Endocrinology 185 467-476.

Priego T, Granado M, Castillero E, Martín AI, Villanúa MA \& LópezCalderón A 2006 Nitric oxide production by hepatocytes contributes to the inhibitory effect of endotoxin on insulin-like growth factor I gene expression. Journal of Endocrinology 190 847-856.

Razzak A, Aldrich C, Babcock TA, Saied A \& Espat NJ 2008 Attenuation of iNOS in an LPS-stimulated macrophage model by Omega-3 fatty acids is independent of COX-2 derived PGE(2). Journal of Surgical Research 145 244-250.

Rodgers BD, Strack AM, Dallman MF, Hwa L \& Nicoll CS 1995 Corticosterone regulation of insulin-like growth factor I, IGF-binding proteins, and growth in streptozotocin-induced diabetic rats. Diabetes 44 $1420-1425$.

Salvemini D, Misko TP, Masferrer JL, Seibert K, Currie MG \& Needleman P 1993 Nitric oxide activates cyclooxygenase enzymes. PNAS 90 7240-7244.

Salvemini D, Settle SL, Masferrer JL, Seibert K, Currie MG \& Needleman P 1995 Regulation of prostaglandin production by nitric oxide; an in vivo analysis. British Journal of Pharmacology 114 1171-1178.

Scharf JG, Braulke T, Hartmann H \& Ramadori G 2001 Regulation of the components of the $150 \mathrm{kDa}$ IGF binding protein complex in cocultures of rat hepatocytes and Kupffer cells by $3^{\prime}, 5^{\prime}$-cyclic adenosine monophosphate. Journal of Cell Physiology 186 425-436.

Shemi D, Azab AN \& Kaplanski J 2001 Time-dependent effect of LPS on PGE2 and TNF-alpha production by rat glial brain culture: influence of COX and cytokine inhibitors. Journal of Endotoxin Research 6 377-381.

Spangelo BL, Judd AM, MacLeod RM, Goodman DW \& Isakson PC 1990 Endotoxin-induced release of interleukin-6 from rat medial basal hypothalami. Endocrinology 127 1779-1785.

Thissen JP 2007 How proinflammatory cytokines may impair growth and cause muscle wasting. Hormone Research 67 64-70.

Thissen JP \& Verniers J 1997 Inhibition by interleukin-1 beta and tumor necrosis factor-alpha of the insulin-like growth factor I messenger ribonucleic acid response to growth hormone in rat hepatocyte primary culture. Endocrinology 138 1078-1084.

Treffkorn L, Scheibe R, Maruyama T \& Dieter P 2004 PGE2 exerts its effect on the LPS-induced release of TNF-alpha, ET-1, IL-1alpha, IL-6 and IL-10 via the EP2 and EP4 receptor in rat liver macrophages. Prostaglandins and other Lipid Mediators 74 113-123. 
Unterman TG, Jentel JJ, Oehler DT, Lacson RG \& Hofert JF 1993 Effects of glucocorticoids on circulating levels and hepatic expression of insulin-like growth factor (IGF)-binding proteins and Igf1 in the adrenalectomized streptozotocin-diabetic rat. Endocrinology 133 2531-2539.

Villafuerte BC, Zhao W, Herington AC, Saffery R \& Phillips LS 1997 Identification of an insulin-responsive element in the rat insulin-like growth factor-binding protein-3 gene. Journal of Biological Chemistry 272 5024-5030

Yang T, Zhang A, Pasumarthy A, Zhang L, Warnock Z \& Schnermann JB 2006 Nitric oxide stimulates COX-2 expression in cultured collecting duct cells through MAP kinases and superoxide but not cGMP. American Journal of Physiology-Renal Physiology 291 F891-F895.
Yumet G, Shumate ML, Bryant P, Lin CM, Lang CH \& Cooney RN 2002 Tumor necrosis factor mediates hepatic growth hormone resistance during sepsis. American Journal of Physiology-Endocrinology and Metabolism 283 E472-E481.

Received in final form 16 May 2008

Accepted 20 May 2008

Made available online as an Accepted Preprint 20 May 2008 